\title{
PENGARUH KEBIASAAN KONSUMSI ENERGI, PROTEIN, DAN SENG TERHADAP KEJADIAN STUNTING PADA ANAK USIA SEKOLAH DASAR DI KECAMATAN SALAPIAN KABUPATEN LANGKAT TAHUN 2017
}

\section{The Effect of Energy, Protein, and Central Consumption Habits on Stunting Events in Basic School Children in Langkat 2017}

\author{
Rismeni Saragih ${ }^{1}$ \\ ${ }^{1}$ Dosen Prodi D-III Kebidanan, Akademi Kebidanan Kharisma Husada \\ E-mail: $\underline{\text { rismeni1075@gmail.com }}$
}

\begin{abstract}
Abstrak
Stunting merupakan salah satu bentuk kelainan gizi dari segi ukuran tubuh yang ditandai dengan keadaan tubuh yang pendek hingga melampaui defisit -2 SD di bawah standar WHO. Penelitian ini bertujuan untuk mengetahui pengaruh kebiasaan konsumsi energi, protein, dan seng terhadap kejadian stunting pada anak usia sekolah di Desa Tanjung Langkat Kecamatan Salapian Kabupaten Langkat. Penelitian ini merupakan penelitian observasional analitik dengan desain penelitian case control. Jumlah sampel penelitian yaitu 29 kasus dan 29 kontrol yang dipilih dengan menggunakan metode stratified random sampling. Pengambilan data kebiasaan konsumsi energi, protein, dan seng dilakukan dengan cara wawancara menggunakan form food recall 24 jam dan form food frequency dan data stunting diperoleh dari pengukuran tinggi badan dan berat badan dengan menggunakan microtoise yang diolah dengan menggunakan Software WHO Anthroplus. Analisis data dilakukan dengan analisis univariat, analisis bivariate dan analisis multivariant dengan menggunakan uji chi-square dan uji regresi logistik. Hasil penelitian menunjukkan bahwa terdapat tiga variabel yang memiliki hubungan bermakna terhadap kejadian stunting yaitu kebiasaan konsumsi energi ( $p=0,036$; OR $=3,109)$, kebiasaan konsumsi protein $(p=0,035 ; \mathrm{OR}=3,148)$ dan kebiasaan konsumsi seng $(p=0,002$; OR $=5,971)$. Faktor yang paling dominan memengaruhi kejadian stunting adalah kebiasaan konsumsi seng dengan Exp. (B) = 5,737. Disarankan untuk meningkatkan pemberian informasi dan pemahaman kepada anak dan orang tua mengenai pentingnya mengonsumsi jenis makanan sumber energi, protein dan seng serta diharapkan kepada orang tua untuk memperhatikan dan membiasakan anak mengonsumsi jenis makanan yang beragam dan disarankan kepada pihak sekolah untuk bekerja sama dengan petugas puskesmas agar memberikan penyuluhan terkait konsumsi makanan yang bergizi seimbang, terutama yang berperan dalam pertumbuhan anak.
\end{abstract}

Kata kunci: Konsumsi energy dan protein, konsumsi seng, stunting, anak usia sekolah

\begin{abstract}
Stunting is one form of nutritional abnormalities in terms of body size characterized by a short body condition to exceed the -2SD deficit below the WHO standard. This study aims to determine the effect of consumption habits of energy sources, protein, and zinc to the incidence of stunting in school-aged children in Tanjung Langkat Village Kecamatan Salapian Kabupaten Langkat. This research is an observational analytic research with case control design. The number of research samples were 29 cases and 29 controls selected using stratified random sampling method. Data of energy consumption habits, protein, and zinc was done by interview using 24 hour food recall form and form food frequency and stunting data obtained from measurement of body height by using microtoise which processed by using Software WHO Anthroplus. Data analysis was done by univariante analysis, bivariate analysis, and multivariate analysis by using chi-square test and logistic regression test. The result of the analysis showed that there were three variables that had significant relation on the stunting event, energy consumption habits $(\mathrm{p}=0.036$; $\mathrm{OR}=3.109)$, protein consumption habits $(\mathrm{p}=0.035 ; \mathrm{OR}=3.148)$ and zinc consumption habits $(\mathrm{p}=0.002 ; \mathrm{OR}=5,971)$. The most dominant factor influencing the stunting event is the consumption habit of zinc source with Exp. $(\mathrm{B})=5.737$. It is advisable to improve the provision of information and understanding to children and parents about the importance of consuming food sources of energy, protein, and zinc as well as expected to parents to pay attention and familiarize children consuming diverse types of food and suggested to the school to cooperate with puskesmas provide counseling related to the consumption of balanced nutritious foods, especially those that play a role in the growth of children.
\end{abstract}

Keywords: Consumption of energy and protein, consumption of zinc, stunting, school-age children 


\section{PENDAHULUAN}

Kualitas bangsa dimasa depan ditentukan oleh kualitas anak bangsa saat ini, karna mereka merupakan investasi bangsa. Anak bangsa ini diharapkan dapat menjadi generasi penerus bangsa yang tangguh. Upaya peningkatan sumber daya manusia harus dilakukan sejak dini dan sitematis serta berkesinambungan. Pemberian gizi dengan kualitas dan kuantitas yang baik serta benar mempengaruhi tumbuh kembang anak usia sekolah untuk mencapai tumbuh kembang yang optimal. Masalah gizi pada anak usia sekolah dapat menyebabkan rendahnya kualitas tingkat pendidikan, tingginya angka absensi dan tingginya angka putus sekolah (WKPG, 1998 dalam Sulastri, 2012).

Kebiasaan konsumsi adalah suatu pola perilaku konsumsi pangan yang diperoleh karena terjadi berulang-ulang. Lingkungan dalam keluarga juga sangat mempengaruhi anak sekolah dalam perilakunya mengkonsumsi makanan dan minuman, hal ini terkait dengan kebiasaan atau pola makan dalam keluarga. Pola makan seorang anak dalam suatu keluarga sangat dipengaruhi oleh pola makan yang diterapkan dan diajarkan oleh orangtuanya, terutama ibu yang menyusun dan mengolah menu dan bahan makanan bagi keluarga setiap hari (Susanto, 2004). Seorang anak yang stunting umumnya tidak terlihat seperti anak yang bermasalah sehingga masih banyak orang tua yang tidak menyadari masalah stunting pada anak, dan dianggap seperti umum saja bila dari orang tua yang pendek maka wajar bila anak-anaknya juga pendek.

Stunting pada anak, selain disebabkan oleh defisiensi zat gizi makro, juga berhubungan dengan defisiensi seng ( $\mathrm{Zn}$ ). Seng ( $\mathrm{Zn})$ adalah mineral esensial yang berperan dalam sintesis, sekresi, dan kontrol hormon pertumbuhan (Growth Hormon). Rendahnya sintesis hormon pertumbuhan dapat menghambat pertumbuhan linier dan diduga menyebabkan kondisi stunting pada masa balita (Hidayati, 2011).

Data dunia menunjukkan $90 \%$ anak yang mengalami stunting atau pendek berada di Asia dan Afrika, hal ini masih merupakan masalah kesehatan masyarakat yang belum terselesaikan (Wardlaw dkk., 2012). Prevalensi anak stunting usia 7-12 tahun di Indonesia sangat tinggi. WHO menetapkan batas toleransi stunting (bertubuh pendek) maksimal $20 \%$ atau seperlima dari jumlah keseluruhan balita. Sementara, di Indonesia tercatat 7,8 juta dari 23 juta balita adalah penderita stunting atau sekitar 35,6\%. Sebanyak $18,5 \%$ kategori sangat pendek dan $17,1 \%$ kategori pendek. Ini juga yang mengakibatkan WHO menetapkan Indonesia sebagai Negara dengan status gizi buruk.

Stunting tertinggi terdapat di Sulawesi Tengah dengan jumlah mencapai 16,9\% dan terendah ada di Sumatera Utara dengan 7,2 $\%$. Dalam Rencana Pembangunan Jangka Menengah Nasional (RPJMN), pemerintah menargetkan penurunan prevalensi stunting dari status awal 32,9\% turun menjadi $28 \%$ pada tahun 2019. Untuk pengurangan angka stunting, pemerintah juga telah menetapkan 100 kabupaten prioritas yang akan ditangani di tahap awal, dan kemudian dilanjutkan 200 kabupaten lainnya (24 Januari 2018).

Berdasarkan Data Dinas Kesehatan Sumatra Utara $28 \%$ balita mengalami stunting, Hal itu diungkapkan Dita Indah Sari dalam paparannya sebagai narasumber pada Seminar Dana Desa Rabu (14/11), di Hotel Danau Toba, Medan.Berdasarakan Riskesdas 2013 prevalensi stunting di sana memang mencapai 55,48\%. Namun pemerintah kemudian melakukan pendataan ulang stunting di wilayah 10 lokus stunting pada Januari 2018.Dari pendataan ulang tersebut diketahui prevalensi stunting menurun menjadi 23,3\%. 10 lokus stunting itu adalah 5 Desa Stunting di Teluk Haru, 4 Desa stunting di Langkat Hilir, dan sisanya di Langkat Hulu 1 Desa stunting.

Berdasarkan penelitian yang dilakukan oleh Dewi dan Adhi (2016) terdapat pengaruh yang bermakna pada konsumsi protein, konsumsi seng dan riwayat penyakit infeksi terhadap kejadian stunting. Selain itu, pada penelitian Mardewi (2014) disimpulkan bahwa kadar seng yang rendah merupakan faktor risiko perawakan pendek pada anak dan asupan energi (kalori) yang rendah juga merupakan faktor risiko perawakan pendek pada anak. Beberapa penelitian (Nador, 2011), (Wardani, 2007), 
dan (Arifin dkk., 2012) dengan desain penelitian case control menyatakan bahwa asupan gizi dan riwayat penyakit memilikihubungan yang signifikan dengan kejadian stunting ( $p=0,013$ dan $\mathrm{OR}=4,14$ ), $(p=0,021$ dan $\mathrm{OR}=2,2)$, dan $(p=0,007$ dan $\mathrm{OR}=2,6)$.

Berdasarkan hasil survei pendahuluan yang dilakukan oleh peneliti, dari 40 anak sebanyak 25 anak mengalami stunting dengan rincian 8 anak kategori sangat pendek dan 17 anak kategori pendek dan dari 25 anak tersebut terdapat 18 anak dengan kebiasaan konsumsi energi sedang, 14 anak dengan kebiasaan konsumsi protein rendah, dan 13 anak dengan kebiasaan konsumsi seng rendah berdasarkan AKG (2013). Oleh karena itu, peneliti tertarik untuk mengetahui "Pengaruh kebiasaan konsumsi energi, protein, dan seng terhadap kejadian stunting pada anak usia sekolah di Desa Tanjung Langkat Kecamatan Salapian Kabupaten Langkat”.

\section{BAHAN DAN METODE}

Penelitian ini menggunakan rancangan penelitian observasional analitik dengan desain case control. Case control merupakan suatu desain penelitian yang bersifat retrospektif yaitu dengan mengidentifikasi kelompok kasus dan kontrol terlebih dahulu, kemudian diidentifikasi dengan faktor risiko terjadinya pada masa lampau. Sehingga dapat menerangkan mengapa kelompok kasus dapat terkena efeknya dan kelompok kontrol tidak (Riyanto, 2011). Penelitian ini dimulai dengan mengidentifikasi subjek yang mengalami stunting (kelompok kasus) dan mencari subyek yang tidak mengalami stunting (kelompok kontrol).
Lokasi penelitian dilakukan di Desa Tanjung Langkat yang berada di Kecamatan Salaian Kabupaten Langkat. Alasan pemilihan lokasi penelitian adalah karena berdasarkan survei pendahuluan yang dilakukan bahwa dari 25 anak tersebut terdapat 18 anak dengan kebiasaan konsumsi energi sedang, 14 anak dengan kebiasaan konsumsi protein rendah, dan 13 anak dengan kebiasaan konsumsi seng rendah berdasarkan AKG (2013).

Populasi penelitian adalah subjek yang memenuhi kriteria yang telah ditetapkan. Populasi dalam penelitian ini adalah seluruh siswa/i di Desa Tanjung Langkat Kecamatan Salapian Kabupaten Langkat.

Sampel penelitian adalah objek yang diteliti dan dianggap mewakili seluruh populasi penelitian, sehingga dalam pengambilan sampel dibutuhkan teknik tertentu agar hasil penelitian valid (Notoatmodjo, 2010). Adapun kriteria dalam menentukan sampel pada penelitian ini adalah dengan menggunakan kriteria eksklusi. Maka sampel pada penelitian ini adalah 58 sampel, dengan rincian 29 sampel sebagai kasus dan 29 sampel sebagai kontrol. Pengambilan sampel secara Stratified Random Sampling.

\section{HASIL}

\section{Kebiasaan Konsumsi Energi}

Kebiasaan konsumsi energi meliput frekuensi dan jenis makanan yang diperoleh dari hasil pengisian formulir food frequency yang diukur dengan cara menjumlahkan skor kemudian dikelompokkan menjadi beberapa kategori. Berdasarkan penelitian yang telah dilakukan, hasil kebiasaan konsumsi energi dapat dilihat pada tabel-tabel berikut ini :

\section{Tabel 1. Distribusi Responden Berdasarkan Frekuensi dan Jenis Makanan Sumber}

Energi

\begin{tabular}{|c|c|c|c|c|c|c|c|c|c|c|}
\hline \multirow{3}{*}{$\begin{array}{l}\text { Jenis } \\
\text { Makana } \\
\text { n }\end{array}$} & \multicolumn{8}{|c|}{ Frekuensi } & \multirow{2}{*}{\multicolumn{2}{|c|}{$\begin{array}{l}\text { Jumla } \\
\text { h }\end{array}$}} \\
\hline & \multicolumn{2}{|c|}{$\begin{array}{r}1- \\
3 x / h a r i\end{array}$} & \multicolumn{2}{|c|}{ 5x/minggu } & \multicolumn{2}{|c|}{ 2x/bulan } & \multicolumn{2}{|c|}{$\begin{array}{c}\text { Jarang/Tdk } \\
\text { Pernah }\end{array}$} & & \\
\hline & $\mathbf{f}$ & $\%$ & $\mathbf{F}$ & $\%$ & $\mathbf{f}$ & $\%$ & $\mathbf{f}$ & $\%$ & $\mathbf{F}$ & $\%$ \\
\hline Nasi & 60 & 100 & 0 & 0 & 0 & 0 & 0 & 0 & 60 & 100 \\
\hline Jagung & 0 & 0 & 7 & 12,0 & 27 & 45,0 & 26 & 43,0 & 60 & 100 \\
\hline
\end{tabular}




\begin{tabular}{lllrrrrrrrr}
\hline Singkong & 0 & 0 & 0 & 0 & 19 & 32,5 & 41 & 67,5 & 60 & 100 \\
Kentang & 0 & 0 & 14 & 24,0 & 30 & 50,0 & 16 & 26,0 & 60 & 100 \\
Mie & 0 & 0 & 46 & 79,0 & 14 & 21,0 & 0 & 0 & 60 & 100 \\
Biskuit & 0 & 0 & 28 & 48,2 & 32 & 51,7 & 0 & 0 & 60 & 100 \\
Bihun & 0 & 0 & 15 & 25,8 & 25 & 40,0 & 20 & 34,4 & 60 & 100 \\
Roti & 0 & 0 & 38 & 65,5 & 22 & 34,4 & 0 & 0 & 60 & 100 \\
\hline
\end{tabular}

Berdasarkan Tabel 1 di atas dapat dilihat bahwa seluruh anak (100\%) mengonsumsi nasi dengan frekuensi 1$3 \mathrm{x} /$ hari. Jenis makanan yang dikonsumsi dengan frekuensi 4-5x/minggu adalah mie sebanyak 46 responden $(79,0 \%)$, sedangkan jenis makanan yang paling sedikit dikonsumsi adalah jagung yaitu 7 responden $(12,0 \%)$ dengan frekuensi $4-$ $5 \mathrm{x} /$ minggu.

Tabel 2. Distribusi Frekuensi Responden Berdasarkan Kebiasaan Konsumsi Energi

\begin{tabular}{llc}
\hline $\begin{array}{l}\text { Kebiasaan } \\
\text { Konsumsi }\end{array}$ & F & \% \\
Energi & & \\
\hline Rendah & 28 & 48,3 \\
Tinggi & 32 & 51,7 \\
\hline Total & $\mathbf{6 0}$ & $\mathbf{1 0 0 , 0}$ \\
\hline
\end{tabular}

Berdasarkan tabel 2 dapat dilihat bahwa anak dengan kebiasaan konsumsi energi yang tinggi lebih banyak yaitu 32

\section{Kebiasaan Konsumsi Protein}

Kebiasaan konsumsi protein meliputi frekuensi dan jenis makanan yang diperoleh dari hasil pengisian formulir food frequency yang diukur dengan cara menjumlahkan anak $(51,7 \%)$ sedangkan untuk kebiasaan konsusmsi energi yang rendah yaitu 28 anak $(48,3 \%)$.

skor kemudian dikelompokkan menjadi beberapa kategori. Berdasarkan penelitian yang telah dilakukan, hasil kebiasaan konsumsi protein dapat dilihat pada tabeltabel berikut ini:

Tabel 3. Distribusi Frekuensi Responden Berdasarkan Kebiasaan Konsumsi Protein

Kebiasaan
Konsumsi
Protein

\begin{tabular}{ccc}
\hline Rendah & 34 & 55,2 \\
Tinggi & 26 & 44,8 \\
\hline Total & $\mathbf{6 0}$ & $\mathbf{1 0 0 , 0}$ \\
\hline
\end{tabular}

Berdasarkan tabel 3 dapat dilihat sedangkan untuk kebiasaan konsusmsi bahwa kebiasaan konsumsi protein yang protein yang tinggi lebih sedikit yaitu 26 rendah lebih banyak yaitu 34 anak $(55,2 \%) \quad$ anak $(44,8 \%)$.

\section{Kebiasaan Konsumsi Seng}

Kebiasaan konsumsi seng meliputi frekuensi dan jenis makanan yang diperoleh dari hasil pengisian formulir food frequency yang diukur dengan cara menjumlahkan skor kemudian dikelompokkan menjadi beberapa kategori. Berdasarkan penelitian yang telah 
dilakukan, hasil kebiasaan konsumsi seng

dapat dilihat pada tabel-tabel berikut ini :

Tabel 4. Distribusi Responden Berdasarkan Frekuensi dan Jenis Makanan Sumber Seng

\begin{tabular}{|c|c|c|c|c|c|c|c|c|c|c|}
\hline \multirow{3}{*}{$\begin{array}{l}\text { Jenis } \\
\text { Makanan }\end{array}$} & \multicolumn{8}{|c|}{ Frekuensi } & & \\
\hline & \multicolumn{2}{|c|}{$\begin{array}{r}1- \\
3 x / h a r i\end{array}$} & \multicolumn{2}{|c|}{$\begin{array}{r}4- \\
5 x / m i n g g u\end{array}$} & \multicolumn{2}{|c|}{$\begin{array}{l}1- \\
2 x / \text { bulan }\end{array}$} & \multicolumn{2}{|c|}{$\begin{array}{c}\text { Jarang/Td } \\
\text { k } \\
\text { Pernah }\end{array}$} & \multicolumn{2}{|c|}{ Jumlah } \\
\hline & f & $\%$ & $\mathbf{F}$ & $\%$ & $\mathbf{F}$ & $\%$ & $\mathbf{f}$ & $\%$ & $\mathbf{f}$ & $\%$ \\
\hline Kepiting & 0 & 0 & 0 & 0 & 13 & 22,4 & 47 & 77,6 & 60 & 100 \\
\hline Wortel & 0 & 0 & 0 & 0 & 16 & 27,6 & 44 & 72,4 & 60 & 100 \\
\hline Ikan Laut & 10 & 17,2 & 38 & 62,1 & 12 & 20,6 & 0 & 0 & 60 & 100 \\
\hline Cumi-cumi & 0 & 0 & 0 & 0 & 18 & 31,0 & 42 & 68,9 & 60 & 100 \\
\hline Brokoli & 0 & 0 & 0 & 0 & 6 & 10,3 & 54 & 89,6 & 60 & 100 \\
\hline Bayam & 0 & 0 & 5 & 8,6 & 23 & 40,0 & 32 & 51,4 & 60 & 100 \\
\hline $\begin{array}{l}\text { Kacang } \\
\text { Panjang }\end{array}$ & 0 & 0 & 10 & 16,2 & 31 & 51,1 & 19 & 32,7 & 60 & 100 \\
\hline
\end{tabular}

Berdasarkan tabel 4 di atas, dapat dilihat bahwa jenis makanan yang jarang/tidak pernah dikonsumsi adalah brokoli yaitu 54 anak (89,6\%), sedangkan jenis makanan yang paling sedikit dikonsumsi dengan frekuensi $1-2 \mathrm{x} /$ bulan adalah bayam yaitu 5anak $(8,6 \%)$.

Tabel 5. Distribusi Frekuensi Responden Berdasarkan Kebiasaan Konsumsi Seng

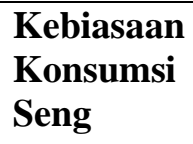

\begin{tabular}{|c|c|c|}
\hline Rendah & 34 & 55,2 \\
\hline Tinggi & 26 & 44,8 \\
\hline Total & 60 & 100,0 \\
\hline
\end{tabular}

Berdasarkan tabel 5 dapat dilihat bahwa kebiasaan konsumsi seng yang rendah lebih banyak yaitu 32 anak $(55,2 \%)$

\section{Tingkat Kecukupan Energi}

Penelitian yang dilakukan terhadap 58 responden di Desa Tanjung Langkat Kecamatan Salapian Kabupaten Langkat sedangkan untuk kebiasaan konsusmsi seng yang tinggi lebih sedikit yaitu 26 anak $(44,8 \%)$.

diperoleh distribusi frekuensi berdasarkan tingkat kecukupan energi. 
Tabel 6. Tabulasi Silang Tingkat Kecukupan Energi Dengan Kejadian Stunting

\begin{tabular}{lcccc}
\hline & \multicolumn{4}{c}{ Kejadian Stunting } \\
\cline { 2 - 5 } $\begin{array}{l}\text { Tingkat } \\
\text { Kecukupan }\end{array}$ & \multicolumn{3}{c}{ Stunting } & Normal \\
Energi & \multicolumn{5}{c}{} & $\mathbf{F}$ & $\mathbf{\%}$ \\
\cline { 2 - 5 } & 20 & 65,5 & 5 & 17,2 \\
Kurang & 10 & 34,5 & 25 & 82,8 \\
Baik & 30 & 100,0 & 30 & 100,0
\end{tabular}

Berdasarkan tabel 6 dapat dilihat bahwa anak yang stunting dengan tingkat kecukupan energi yang kurang sebanyak yaitu 20 anak (65,5\%), sedangkan yang baik sebanyak 10 anak (34,5\%). Anak yang normal dengan tingkat kecukupan

\section{Tingkat Kecukupan Protein}

Penelitian yang dilakukan terhadap 60 responden di Desa Tanjung Langkat Kecamatan Salapian Kabupaten Langkat energi yang kurang hanya 5 anak $(17,2 \%)$, sedangkan yang baik sebanyak 25 anak $(82,8 \%)$.

diperoleh distribusi frekuensi berdasarakan tingkat kecukupan protein. Data selengkapnya dapat dilihat pada tabel 4.11 sebagai berikut:

Tabel 7. Tabulasi Silang Tingkat Kecukupan Protein Dengan Kejadian Stunting

\begin{tabular}{ccccc}
\hline & \multicolumn{4}{c}{ Kejadian Stunting } \\
\cline { 2 - 5 } Tingkat \\
\cline { 2 - 5 } $\begin{array}{c}\text { Kecukupan } \\
\text { Protein }\end{array}$ & & Stunting & Normal \\
\cline { 2 - 5 } & & & F & \% \\
\hline Kurang & 22 & 72,4 & 7 & 24,1 \\
Baik & 8 & 27,6 & 23 & 75,9 \\
\hline Total & 30 & 100,0 & 30 & 100,0 \\
\hline
\end{tabular}

Berdasarkan tabel 7 dapat dilihat bahwa anak yang stunting dengan tingkat kecukupan protein yang kurang sebanyak yaitu 22 anak $(72,4 \%)$, sedangkan yang baik hanya 8 anak $(27,6 \%)$. Anak yang

\section{Tingkat Kecukupan Seng}

Penelitian yang dilakukan terhadap 58 responden di Desa Tanjung Langkat

\section{Hubungan Kebiasaan Konsumsi Seng Dengan Kejadian Stunting}

Kebiasaan konsumsi seng dilihat dari gambaran pola konsumsi bahan makanan atau makanan jadi selama periode tertentu normal dengan tingkat kecukupan protein yang kurang hanya 7 anak $(24,1 \%)$, sedangkan yang baik sebanyak 23 anak $(75,9 \%)$.

Kecamatan Salapian Kabupaten Langkat diperoleh distribusi frekuensi berdasarkan tingkat kecukupan seng.

seperti hari, minggu, bulan atau tahun (Supariasa, 2002). Data kebiasaan konsumsi seng yang telah diambil kemudian dikategorikan. Hubungan kebiasaan konsumsi seng dengan kejadian stunting dapat dilihat pada tabel berikut ini: 
Tabel 8. Tabulasi Silang Kebiasaan Konsumsi Seng dengan Kejadian Stunting

\begin{tabular}{|c|c|c|c|c|c|c|}
\hline \multirow{3}{*}{$\begin{array}{l}\text { Kebiasaan } \\
\text { Konsumsi } \\
\text { Seng }\end{array}$} & \multicolumn{5}{|c|}{ Kejadian Stunting } & \multirow{3}{*}{ OR } \\
\hline & \multicolumn{2}{|c|}{ Stunting } & \multicolumn{2}{|c|}{ Normal } & \multirow[t]{2}{*}{$P$} & \\
\hline & $\mathbf{f}$ & $\%$ & $\mathbf{F}$ & $\%$ & & \\
\hline Rendah & 23 & 75,9 & 10 & 34,5 & 0,002 & 5,971 \\
\hline Tinggi & 7 & 24,1 & 20 & 65,5 & & \\
\hline Total & 30 & 100,0 & 30 & 100,0 & & \\
\hline
\end{tabular}

Berdasarkan tabel 8 di atas diketahui bahwa proporsi stunting untuk kebiasaan konsumsi seng yang rendah sebanyak 23 anak $(75,9 \%)$, sedangkan yang tinggi hanya 7 anak $(24,1 \%)$. Anak yang normal dengan kebiasaan konsumsi seng yang rendah sebanyak 10 anak $(34,5 \%)$, sedangkan yang tinggi sebanyak 20 anak $(65,5 \%)$.

\section{Pengaruh Kebiasaan Konsumsi Energi, Protein, dan Seng Terhadap Kejadian Stunting}

Berdasarkan hasil uji bivariat diperoleh variabel independen yang memenuhi
Hasil analisis statistik dengan menggunakan uji chi-square menunjukkan bahwa, terdapat hubungan yang bermakna antara kebiasaan konsumsi seng dengan kejadian stunting ( $p=0,002 ; \mathrm{OR}=5,971)$. Dengan demikian kebiasaan konsumsi sumber seng yang rendah memiliki risiko 5,971 kali mengalami stunting dibandingkan dengan yang normal.

kriteria kemaknaan $(p<0,25)$ sehingga dapat ikut dalam analisis multivariat dengan menggunakan uji regresi logistik berganda metode enter. Secara rinci dapat dilihat pada tabel berikut :

Tabel 9. Variabel Independen Yang Masuk Dalam Analisis Multivariat

\begin{tabular}{clc}
\hline No. & Variabel & $\boldsymbol{P}$ \\
\hline 1 & Kebiasaan Konsumsi Energi & 0,036 \\
2 & Kebiasaan Konsumsi Protein & 0,035 \\
3 & Kebiasaan Konsumsi Seng & 0,002 \\
\hline
\end{tabular}

Dari tabel 9 di atas dapat dilihat bahwa variabel-variabel yang di analisis multivariat adalah variabel dengan nilai $p<0,25$ yaitu kebiasaan konsumsi energi, protein, dan seng

\section{PEMBAHASAN}

\section{Hubungan Kebiasaan Konsumsi Energi Dengan Kejadian Stunting}

Berdasarkan hasil penelitian yang telah dilakukan, dapat diketahui bahwa kebiasaan konsumsi energi pada anak stunting berada dalam kategori rendah. Adapun jumlah anak stunting yang memiliki kebiasaan konsumsi energi yang rendah sebanyak 19 anak (62,1\%) sedangkan anak untuk menyingkirkan bias terhadap hasil penelitian ini. Analisis multivariat variabel yang berpengaruh dengan kejadian stunting disajikan dalam tabel berikut :

yang memiliki kebiasaan konsumsi energi yang tinggi hanya 11 anak $(37,9 \%)$.

Berdasarkan hasil analisis statistik dengan menggunakan uji chi-square menunjukkan bahwa, terdapat hubungan yang bermakna antara kebiasaan konsumsi energi dengan kejadian stunting ( $p=0,036$; $\mathrm{OR}=3,109)$. Pada penelitian ini juga dapat dilihat bahwa nilai $\mathrm{OR}=3,109$, yang berarti anak yang mengalami stunting berasal dari anak yang memiliki kebiasaan konsumsi 
energi yang rendahdengan risiko 3 kali lebih tinggi.

dari $\begin{gathered}\text { Kebiasaan konsumsi energi dilihat } \\ \text { gambaran pola konsumsi bahan }\end{gathered}$ makanan atau makanan jadi selama periode tertentu seperti hari, minggu, bulan atau tahun.Kebiasaan konsumsi ini meliputi jenis dan frekuensi konsumsi energi oleh anak yang diperoleh dengan menggunakan formulir food frequency. Sebagian besar jenis makanan dari sumber energi yang dikonsumsi anak SD di Desa Tanjung Langkat adalah nasi dengan frekuensi 1$3 x /$ hari.Hal ini dapat diketahui karena pada setiap kali mengonsumsi makanan utama responden selalu menyediakan nasi sebagai makanan pokok (sumber energi). Disamping itu, nasi merupakan makanan pokok yang dikonsumsi oleh keluarga secara turuntemurun seperti yang disebutkan oleh Suhardjo (1988) dan Truswell (1992) yang dikutip oleh Gunanti (2006) bahwa kebiasaan makan pada seseorang bersifat turun-temurun dan kemudahan untuk memperolehnya. Anak usia sekolah umumnya mengonsumsi makanan menurut kesukaan mereka tanpa memperhatikan zat gizi apa yang terdapat dalam makanan tersebut. Mereka yang lebih banyak menghabiskan waktu di sekolah, cenderung lebih sering mengonsumsi makanan yang ada di sekolah dibandingkan dengan di rumah.

Berdasarkan tingkat kecukupan energi yang diperoleh menggunakan foodrecall dapat diketahui bahwa anak yang stunting dengan tingkat kecukupan energi yang kurang sebanyak yaitu 20 anak $(65,5 \%)$, sedangkan yang baik sebanyak 10 anak $(34,5 \%)$. Anak yang normal dengan tingkat kecukupan energi yang kurang hanya 5 anak $(17,2 \%)$, sedangkan yang baik sebanyak 25 anak $(82,8 \%)$. Hal ini menunjukkan bahwa rata-rata konsumsi energi anak stunting dalam sehari masih kurang dari Angka Kecukupan Gizi (AKG) yang telah dianjurkan.Hal ini dapat disebabkan oleh makanan yang dikonsumsi sehari-hari oleh anak stunting baik di rumah maupun di sekolah, seperti jajanan yang ada di sekolah yang belum bisa mencukupi kebutuhan energi yang dibutuhkan dalam sehari.Kebiasaan anak yang jarang sarapan pagi, jumlah asupan makanan pokok yang kurang dan frekuensi makan makanan pokok yang dikonsumsi hanya 4-5x/minggu bahkan ada yang jarang/tidak pernah dikonsumsi yang mengakibatkan kebutuhan energi anak belum tercukupi.

Hasil penelitian yang dilakukan oleh Muchlis, dkk (2011) dengan menggunakan chi-square menunjukkan hasil bahwa terdapat hubungan antaraasupan energi dengan status gizi menurut indikator $\mathrm{TB} / \mathrm{U}$ denagn $(p=0,027)$. Hal ini berarti bahwa balita dengan asupan energi yang baik yaitu $\geq 77 \%$ dari kebutuhan memiliki peluang lebih besar berstatus gizi normal (TB/U). Pada penelitian Mardewi (2014) disimpulkan bahwa asupan energi (kalori) yang rendah juga merupakan faktor risiko perawakan pendek pada anak dengan nilai $p=0,006$.

Energi diartikan sebagai suatu kapasitas untuk melakukan suatu pekerjaan. Jumlah energi yang dibutuhkan seseorang tergantung pada usia, jenis kelamin, berat badan dan bentuk tubuh. Energi dalam tubuh manusia timbul dikarenakan adanya pembakaran karbohidrat, protein dan lemak.Dengan demikian agar dapat tercukupi kebutuhan energinya diperlukan intake zat-zat makanan yang cukup pula ke dalam tubuhnya.

Menurut Lucas dan Feucht (2008), kebutuhan energi anak usia sekolah ditentukan berdasarkan metabolisme basal, kecepatan pertumbuhan, dan pengeluaran energi. Energi dari konsumsi pangan harus cukup untuk memenuhi kebutuhan pertumbuhan dan mencegah protein digunakan sebagai sumber energi tetapi tidak sampai terjadi pertambahan berat badan yang berlebihan. Kebutuhan energi total meningkat sedikit sejalan dengan usia, tetapi kebutuhan energi per kilogram berat badan secara aktual menurun (Whitney \& Rolfes 2011). Untuk anak usia 7-9 tahun, tanpa membedakan jenis kelamin, kebutuhan energinya adalah $1800 \mathrm{kkal}$. Anak laki-laki dan wanita berusia 10-12 tahun memerlukan energi sebesar $2050 \mathrm{kkal}$ (WNPG 2004). 


\section{Hubungan Kebiasaan Konsumsi Protein Dengan Kejadian Stunting}

Berdasarkan hasil penelitian yang telah dilakukan, dapat diketahui bahwa kebiasaan konsumsi protein pada anak stunting berada dalam kategori rendah. Adapun jumlah anak stunting yang memiliki kebiasaan konsumsi protein yang rendah sebanyak 21 anak $(69,0 \%)$, sedangkan anak yang memiliki kebiasaan konsumsi protein yang tinggi hanya 9 anak $(31,0 \%)$.

Berdasarkan hasil analisis statistik dengan menggunakan uji chi-square menunjukkan bahwa, terdapat hubungan yang bermakna antara kebiasaan konsumsi protein dengan kejadian stunting ( $p=0,035$; $\mathrm{OR}=3,148$ ). Pada penelitian ini juga dapat dilihat bahwa nilai $\mathrm{OR}=3,148$, yang berarti anak yang mengalami stunting berasal dari anak yang memiliki kebiasaan konsumsi protein yang rendahdengan risiko 3 kali lebih tinggi.

Kebiasaan konsumsi ini meliputi jenis dan frekuensi konsumsi protein oleh anak yang diperoleh dengan menggunakan formulir food frequency. Sebagian besar jenis makanan dari sumber protein yang dikonsumsi anak SD di Desa Tanjung Langkat adalah tahu, tempe, telur ayam dengan frekuensi 4-5x/minggu. Hal ini dapat diketahui karena responden cenderung menyukai makanan yang praktis, cepat, dan orang tua juga mudah untuk mengolahnya. Biasanya tahu, tempe, dan telur ayam diolah/disajikan hanya dengan cara digoreng. Untuk jenis makanan lain yang dikonsumsi oleh anak adalah udang, daging ayam, kerang, ikan tongkol, dan susu sapi dengan frekuensi 1-2x/bulan, selanjutnya ada beberapa anak yang jarang/tidak pernah mengonsumsi bandeng dan belut, hal ini dikarenakan jenis pangan ini jarang ditemukan dan sebagian orang tua responden kurang bervariasidalam menyediakan makanan untuk anak-anaknya, mereka cenderung monoton dalam menyediakan makanan anak mereka. Selain itu beberapa anak juga tidak menyukainya.Sedangkan daging sapi, responden hanya mengonsumsi jika ada acara-acara besar seperti hajatan atau pesta dan hari-hari besar seperti Hari Raya Idul Fitri dan Idul Adha.
Berdasarkan tingkat kecukupan protein yang diperoleh menggunakan foodrecall dapat diketahui bahwa anak yang stunting dengan tingkat kecukupanprotein yang kurang sebanyak yaitu 22 anak $(72,4 \%)$, sedangkan yang baik hanya 8 anak $(27,6 \%)$.. Anak yang normal dengan tingkat kecukupan protein yang kurang hanya 7 anak $(24,1 \%)$, sedangkan yang baik sebanyak 23 anak (75,9\%).

Hasil penelitian Sundari (2016) didapatkan bahwa ada hubungan positif antara asupan protein dengan indeks $z$-score $\mathrm{TB} / \mathrm{U}$ dengan nilai $p=0,042$. Hasil penelitian yang dilakukan oleh Vaozia (2016) menunjukkan bahwa asupan protein merupakan faktor risiko kejadian stunting pada anak usia 1-3 tahun. Anak dengan asupan protein yang kurang memiliki risiko 1,71 kali untuk menjadi stunting.

Protein dibutuhkan untuk membangun, menjaga, dan memperbaiki jaringan tubuh.Selain itu, protein juga berperan penting dalam pertumbuhan.Protein merupakan zat gizi yang diperlukan oleh tubuh untuk pertumbuhan, membangun struktur tubuh (otot, kulit dan tulang) serta sebagai pengganti jaringan yang sudah usang (Almatsier, 2002).

Berdasarkan hasil penelitian Sulistianingsih dan Ari Madi Yanti tahun 2015 ditemukan bahwa protein berhubungan dengan kejadian stunting $p$-value 0,002 .Hal ini sesuai dengan kajian teori bahwa fungsi protein adalah sebagai zat pembangun.Seluruh lapisan sel terdiri dari protein yang membawa mikronutrien.Protein berfungsi dalam menjalankan regulasi tubuh dan pembentukan DNA baru bagi tubuh. Kekurangan protein dalam jangka panjang akan menyebabkan terganggunya regulasi tubuh dan hormon pertumbuhan dapat terganggu yang dapat menyebabkan gangguan gizi seperti stunting (Rolfes, 2006).

Hasil uji statistik chi square pada penelitian Chastity tahun 2017 juga menunjukkan hubungan yang positif antara asupan protein dengan kejadian stunting pada remaja dengan nilai $p=0,001$ yang berarti terdapat hubungan yangbermakna 
antara asupan protein dengan kejadian stunting.

Eratnya hubungan protein dengan pertumbuhan menyebabkan seorang anak yang kurang asupan proteinnya akan mengalami pertumbuhan yang lebih lambat daripada anak dengan jumlah asupan protein yang cukup (Bender, 2002) dan pada keadaan yang lebih buruk kekurangan protein dalam jangka waktu yang lama dapat mengakibatkan berhentinya proses pertumbuhan (Andarini, Ventiyaningsih, \& Samosir, 2013).

\section{Hubungan Kebiasan Konsumsi Seng Dengan Kejadian Stunting}

Berdasarkan hasil penelitian yang telah dilakukan, dapat diketahui bahwa kebiasaan konsumsi seng pada anak stunting berada dalam kategori rendah. Adapun jumlah anak stunting yang memiliki kebiasaan konsumsi seng yang rendah sebanyak sebanyak 23 anak $(75,9 \%)$, sedangkan yang tinggi yaitu 7 anak $(24,1 \%)$.

Berdasarkan hasil analisis statistik dengan menggunakan uji chi-square menunjukkan bahwa, terdapat hubungan yang bermakna antara kebiasaankonsumsi seng dengan kejadian stunting $(p=0,002$; $\mathrm{OR}=5,971$ ). Pada penelitian ini juga dapat dilihat bahwa nilai $\mathrm{OR}=5,971$, yang berarti anak yang mengalami stunting berasal dari anak yang memiliki kebiasaan konsumsi seng yang rendahdengan risiko 6 kali lebih tinggi.

Kebiasaan konsumsi ini meliputi jenis dan frekuensi konsumsi seng oleh anak yang diperoleh dengan menggunakan formulir food frequency.Untuk jenis makanan dari sumber seng yang dikonsumsi anak SD di Desa Tanjung Langkat dengan frekuensi 1$3 x /$ hari adalah ikan laut, namun hanya sebagian kecil yang mengonsumsinya. Pada umumnya responden lebih menyukai makanan yang praktis untuk dimakan seperti tahu, tempe, dan telur ayam daripada ikan laut yang sebagian besar memiliki duri. Untuk jenis makanan lain yang jarang/tidak pernah dikonsumsi adalah kepiting dan cumi-cumi, hal ini dikarenakan harganya yang sedikit lebih mahal dari jenis makanan lainnya seperti ikan, sedangkan wortel, brokoli, bayam dan kacang panjang juga jarang/tidak pernah dikonsumsi. Ada sebagian anak yang jarang mengonsumsi sayur dengan alasan anak tidak suka dan orang tua yang tidak membiasakan anak untuk makan sayur.

Seng penting diperhatikan karena seng termasuk kedalam mikronutrien esensial bagi tubuh.Beberapa fungsi dari seng adalah berperan dalam imunitas, stabilisasi struktur RNA dan DNA dan juga hormon pertumbuhan.

Hal ini sejalan dengan penelitian yang dilakukan oleh Dewi dan Adhi tahun 2016 yang menunjukkan adanya pengaruh yang bermakna antara konsumsi seng dengan kejadian stunting. Pengaruh konsumsi seng terhadap kejadianstunting terbukti pula dari penelitian Hidayati et al., (2010) bahwa anak yangmemiliki defisiensi seng 2,67 kali lebih berisiko mengalami stunting.

Zink memainkan peran penting dalam pertumbuhan dan sistem imun.Zink diketahui berperan pada lebih dari 300 enzim, baik sebagai bagian dari strukturnya maupun aksi katalik dan regulatorynya.Zink juga berinteraksi dengan hormon-hormon penting yang terlibat dalam pertumbuhan tulang seperti samatomedin-c, osteocalcin, testosterone, hormone thyroid dan insulin. Kadar zink yang sangat tinggi ditulang dibanding dengan jaringan lain ini sangat penting dalam memperkuat maatriks tulang. Zink juga memperlancar efek vitamin D terhadap metabolisme tulang melalui stimulasi sintesis DNA di sel-sel tulang. Oleh karena itu , zink sangat erat kaitannya dengan metabolisme tulang, sehingga zink berperan secara positif pada pertumbuhan dan perkembangan dan sangat penting dalam tahap-tahap pertumbuhan dan perkembangan (Riyadi, 2007).

\section{Pengaruh Kebiasaan Konsumsi Energi, Protein, dan Seng Dengan Kejadian Stunting}

Berdasarkan hasil penelitian yang telah dilakukan menunjukan bahwa faktor yang paling dominan memengaruhi kejadian stunting adalah kebiasaan konsumsi seng dengan nilai $p=0,005$ dengan nilai odds rasio (OR) sebesar 5,737.

Dari berbagai faktor yang berpengaruh terhadap kejadian stunting, 
didapatkan bahwa variabel kebiasaan konsumsi seng sebagai faktor dominan yang mempengaruhi kejadian stunting pada anak SD di Desa Tanjung Langkat Kecamatan Salapian Kabupaten Langkat. Anak yang mengalami stunting berasal dari anak yang kebiasaan konsumsi sumber sengnya rendah, yang berarti anakdengan kebiasaan konsumsi seng yang rendah memiliki risiko sebesar 5,73 kali lebih tinggi untuk mengalami stunting dibandingkan dengan yang normal.

Hal ini sejalan dengan penelitian yang dilakukan oleh Dewi \& Adhi tahun 2016 yang menunjukkan faktor dominan yang mempengaruhi kejadian stunting di wilayah kerja Puskesmas Nusa Penida III adalah konsumsi seng ( $p=0,006 ; \mathrm{OR}=9,94)$.

Defisiensi seng telah mendapat perhatian sebagai etiologi stunting (WHO, 2002).Selain berhubungan dengan pertumbuhan linier anak, seng juga memiliki pengaruh penting terhadap integritas sistem kekebalan tubuh (Agustian et al., 2009; Sloane, 2004).Defisiensi seng juga dapat menurunkan respon antibodi yang bergantung pada sel $\mathrm{T}$ sehingga dapat menyebabkan gangguan imunitas dan meningkatkan risiko terkenan infeksi.Respon terhadap infeksi yang mempengaruhi status gizi berupa penurunan selera makan (anoreksia), malabsorbsi dalam saluran cerna, kehilangan nutrien, dan perubahan metabolisme (Achmadi, 2013). Kebutuhan seng secara fisiologis meningkat pada periode pertumbuhan cepat akibat terjadinya proses replikasi DNA, transkripsi DNA dan fungsi endokrin (Gibson, 2006; Hidayati, 2011). Bayi dan anak - anak berisiko mengalami defisiensi seng karena kadar metalotionein di hati rendah saat lahir, berat badan lahir rendah atau ibu dengan defisiensi seng sedangkan kebutuhan seng untuk tumbuh kejar sangat tinggi (Gibson, 2006).

Penyebab perawakan pendek yang paling umum di seluruh dunia adalah malnutrisi. Nutrisi memegang peranan penting terhadap kontrol mekanisme pertumbuhan linier. Penelitian pada binatang menunjukkan restriksi pemberianenergi dan protein menyebabkan penurunan konsentrasi IGF-1 dalam darah dan akan kembali normal setelah diberikan energi yang sesuai. Hubungan antara status nutrisi dan IGF-1 pada manusia dapat dilihat dari penurunan kadar IGF-1 pada anak dengan malnutrisi seperti kwarsiorkor atau marasmus (Estivariz, 1997 dalam Rivera, 2003).

Kadar seng yang rendah menyebabkan penyebab perawakan pendek dengan mekanisme kekurangan seng menimbulkan anoreksia sehingga asupan energi rendah dan pertumbuhan terganggu.Seng berperan dalam sintesis DNA dan RNA yang penting dalam replikasi dan diferensiasi kondrosit dan osteoblast, transkripsi dan sintesis somatomedin, osteokalsin dan kolagen serta metabolisme karbohidrat, protein dan lemak. Seng mempengaruhi sintesis dan sekresi growthhormon $(\mathrm{GH})$ dan aktivasi insulinlike growth factor 1 (IGF-1) atau somatomedindi hati dan tulang (Salgueiro dkk., 2002).

\section{KESIMPULAN}

Dari hasil penelitian dan pembahasan dapat disimpulkan bahwa ada hubungan antara kebiasaan konsumsi energi dengan kejadian stunting $(\mathrm{OR}=3,109)$, yang berarti anak yang mengalami stunting berasal dari anak yang memiliki kebiasaan konsumsi energi yang rendah dengan risiko 3 kali lebih tinggi.

Terdapat juga hubungan antara kebiasaan konsumsi protein dengan kejadian stunting $(\mathrm{OR}=3,148)$, yang berarti anak yang mengalami stunting berasal dari anak yang memiliki kebiasaan konsumsi protein yang rendah dengan risiko 3 kali lebih tinggi. Ada hubungan antara kebiasaan konsumsi seng dengan kejadian stunting $(\mathrm{OR}=5,971)$, yang berarti anak yang mengalami stunting berasal dari anak yang memiliki kebiasaan konsumsi seng yang rendah dengan risiko 6 kali lebih tinggi.

Variabel yang paling dominan berpengaruh dengan kejadian stunting pada anak usia sekolah di SD di Desa Tanjung Langkat Kecamatan Salapian Kabupaten Langkat adalah kebiasaan konsumsi seng $(\mathrm{OR}=5,737)$. Anak yang mengalami stunting berasal dari anak yang kebiasaan konsumsi sengnya rendah, yang berarti anak dengan kebiasaan konsumsi seng yang rendah memiliki risiko sebesar 5,73 kali lebih tinggi 
untuk mengalami stunting dibandingkan dengan yang normal.

\section{SARAN}

1. Perlu ditingkatkan pemberian informasi dan pemahaman kepada anak dan orang tua mengenai pentingnya mengonsumsi jenis makanan sumber energi, protein, dan seng serta diharapkan kepada orang tua untuk memperhatikan dan membiasakan anak mengonsumsi jenis makanan yang beragam.

2. Disarankan kepada pihak sekolah untuk bekerjasama dengan petugas puskesmas agar memberikan penyuluhan terkait konsumsi makanan yang bergizi seimbang terutama yang berperan dalam pertumbuhan anak.

\section{DAFTAR PUSTAKA}

Adriani, Merryana dan Bambang Wirjatmadi, 2014, Gizi dan kesehatan Balita Peranan Mikro Zink pada Pertumbuhan Balita, Jakarta: Kencana Prenadamedia Group.

Adriani, Merryana dan Bambang Wirjatmadi, 2014, Peranan Gizi Dalam Siklus Kehidupan. Jakarta: Kencana Prenadamedia Group.

Almatsier, Sunita. 2009. Prinsip Dasar Ilmu Gizi, Jakarta: PT.Gramedia Pustaka Utama.

Almatsier, S., Soetardjo, S., \& Soekatri, M. 2011. Gizi Seimbang dalam Dasar Kehidupan. Jakarta: PT. Gramedia Pustaka Utama.

Baliwati, yf. DKK, 2004. Pengantar Pangan dan Gizi. Jakarta: Penebar Swadaya.

Barus, Dumasari. 2009. "Hubungan Kebiasaan Makan Dan Pemeliharaan Kesehatan Gigi Dengan Karies Gigi Pada Anak Sd 060935 Di Jalan Pintu Air II Simpang Gudang Kota Medan Tahun 2008" (Skripsi). Medan: FKM Universitas Sumatra Utara.

Dayyana, Latanza Shima. 2015 "Faktorfaktor Yang Berhubungan Dengan Kejadian Stunting Anak Usia Sekolah Dasar Pada Siswa/Siswi Madrasah Ibtidaiyah (MI) Muhammadiyah Haurageulis Indramayu"
(Skripsi).Jakarta: FKIK Universitas Islam Negri Syarif Hidayatullah.

Dewi, Ida Ayu K.C, dan Kakek Tresna Adhi. 2016. "Pengaruh Konsumsi Protein Dan Seng Serta Riwayat Penyakit Infeksi Terhadap Kejadian Stunting Pada Anak Balita Umur 24-59 Bulan Di Wilayah Kerja Puskesmas Nusa Penida III". Program Studi Kesehatan Masyarakat Fakultas Kedokteran Universitas Udayana. Vol. 3 No.1 : 36 - 46. Juni 2016. Fuecht SA. 2008. Nutrion in childhood. Di dalam: Mahan LK, Escott-Stump S, editor. Krause's Food, nutrion, and Diet Therapy $12_{\text {th }}$ Edition. Pennsylvania (US): The Curtis Center. Hlm 223-245.

Gibson, R.S., 2005. Principle of Nutrional and Assessment. Oxford UniversityPress, Newyork: 625.

Hariyati, Neni. 2016. "Hubungan Antara Riwayat Infeksi dan Tingkat Konsumsi Dengan Kejadian Stunting Pada Anak Usia 25-59 Bulan" (Skripsi). Jember: FKM Universitas Jember.

Hidayati, L, Hadi, H. \& Kumara, A.2010. "Kekurangan Energi dan Zat Gizi merupakan Faktor Risiko Kejadian Stunted pada Anak Usia 1-3 Tahun yang Tinggal di Wilayah Kumuh Perkotaan Surakarta” Jurnal Kesehatan 3.

Kementrian Kesehatan RI. (2013). Laporan Hasil Riset Kesehatan Dasar (Riskesdas) Tahun 2013. Jakarta: Badan Penelitian dan Pengembangan Kesehatan.

Khomsan, Ali. 2013. Pangan dan Gizi Untuk Kesehatan. Jakarta: PT. Raja Grafindo Persada.

Kusharisupeni, 2011. Peran Status Kelahiran Terhadap Stunting Pada Bayi : Sebuah Studi Prospektif. Jurnal Kedokteran Trisakti, 23(3), 73-80. 